\title{
Analisis Adopsi Media Sosial Sebagai Sarana Pemasaran Digital Bagi UMKM Makanan dan Minuman di Jatinangor
}

\author{
Kurnia Khafidhatur Rafiah \\ Universitas Padjajaran \\ Kurnia.khafidhatur@unpad.ac.id
}

Desty Hapsari Kirana

Universitas Padjajaran

Desty.kirana@unpad.ac.id

\begin{abstract}
Abstrak
Mayoritas UMKM Makanan dan Minuman di daerah Jatinangor belum menggunakan fitur Instagram for Business yang tersedia gratis sebagai media promosi maupun media untuk memasarkan produk yang mereka jual. Instagram for Business diklaim sebagai salah satu fitur media sosial yang mampu meningkatkan efektifitas dalam melakukan pemasaran dengan memanfaatkan media digital.

Ketidaktahuan para pelaku UMKM Makanan dan Minuman di Jatinangor mengenai praktik pemasaran yang menggunakan media digital dan berbiaya rendah, serta minimnya UMKM makanan dan minuman di wilayah Jatinangor yang memanfaatkan fitur Instagram for Business dalam menunjang promosi produk pada usaha miliknya menjadi fokus utama peneliti dalam melakukan penelitian ini.

Berdasarkan hasil survey dan wawancara terhadap 30 pemilik UMKM Makanan dan Minuman di wilayah Jatinangor diketahui terdapat beberapa kendala yang seringkali menghambat mereka dalam memanfaatkan berbagai fitur pemasaran digital. Keterbatasan informasi seringkali menjadi kendala utama yang membuat mereka tidak melakukan adopsi pemasaran digital menggunaka media sosial khususnya fitur Instagram for Business. Minimnya pemanfaatan fitur yang menunjang pemasaran digital ini menyebabkan keterbatasan dalam pemasaran produk yang dimiliki.

Adapun setelah memperoleh informasi dan edukasi mengenai fitur Instagram for Business $90 \%$ dari responden langsung mengaktifkan fitur Instagram for Business khusus untuk usaha yang mereka miliki.
\end{abstract}

Kata Kunci $\quad U M K M$, Pemasaran Digital, Instagram Bisnis

\section{PENDAHULUAN}

Dalam 10 tahun terakhir, Badan Pusat Statistik mencatat bahwa perkembangan ekonomi di Indonesia mengalami pertumbuhan yang positif (Krisnawati, 2018). Menurut Chandra (2017) yang dikutip dari detikFinance, Badan Pusat Statistik juga menjelaskan bahwa pada tahun 2016 pendapatan per kapita Indonesia mengalami kenaikan menjadi Rp 47,96 juta per kapita per tahun. Angka ini mengalami kenaikan dari sisi pendapatan 
per kapita per tahun dari tahun 2015 sebesar Rp 45,14 juta dan pada tahun 2014 Rp 41,92 juta.

Salah satu yang mendukung perkembangan ekonomi di Indonesia yaitu Usaha Mikro Kecil dan Menengah (UMKM). Berdasarkan data dari depkop.go.id, jumlah UMKM di Indonesia dari tahun 2012 sampai dengan 2017 selalu meningkat. Adapun perkembangan jumlah UMKM di Indonesia dari tahun 2012-2017 adalah sebanyak 7.716.172 unit usaha atau sebesar 13,98\%, dengan rincian sebagai berikut:

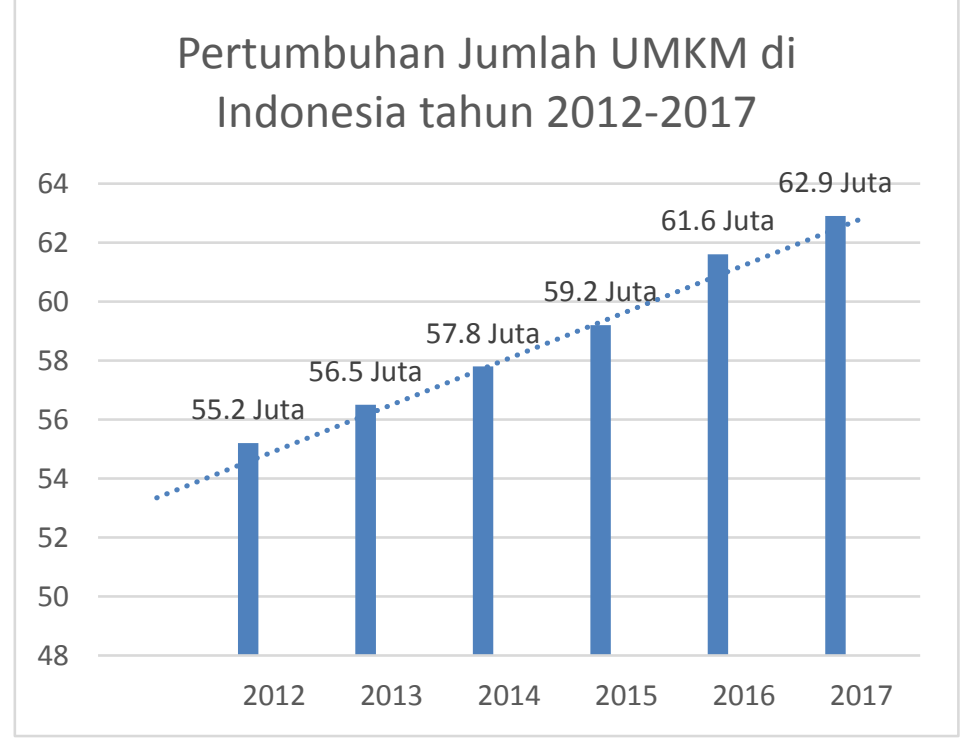

Sumber: depkop.go.id

Semakin bertambahnya jumlah UMKM di Indonesia dari tahun ke tahun, UMKM berkontribusi terhadap pendapatan domestik bruto (PDB) Indonesia. Dikutip dari CNN Indonesia, Mutmainah (2016) menyatakan bahwa kontribusi sektor UMKM terhadap PDB meningkat dari $57,84 \%$ menjadi $60,34 \%$. Selain itu, penyerapan tenaga kerja juga menjadi salah satu peran dari UMKM di Indonesia, terbukti bahwa serapan tenaga kerja pada UMKM meningkat dari 96,99\% menjadi 97,22\% dalam periode 5 tahun terakhir.

Adapun meningkatnya UMKM di Indonesia tak lepas dari kemajuan teknologi digital yang semakin hari semakin canggih. Dengan adanya teknologi digital, konsumen semakin mudah untuk dapat mengakses apapun, termasuk mengakses berbagai informasi mengenai produk dan layanan, bahkan untuk melakukan proses jual beli. Berdasarkan survey yang dilakukan oleh Asosiasi Penyelenggara Jasa Internet Indonesia (APJII), penetrasi pengguna internet di Indonesia pada tahun 2017 meningkat menjadi 143,26 juta jiwa atau setara 54,7 persen dari total populasi penduduk di Indonesia.

Menurut Krisnawati (2018), dari total pengguna internet tersebut, lebih dari 50\% memiliki ponsel pintar (smartphone). Dikutip dari databoks.co.id, diketahui bahwa pengguna telepon seluler (ponsel) di Indonesia mencapai 371,4 juta pengguna atau $142 \%$ dari total populasi sebanyak 262 juta jiwa. Artinya, rata-rata setiap penduduk memakai 1,4 telepon seluler karena satu orang terkadang menggunakan 2-3 kartu telepon seluler. 


\section{Pengguna Ponsel dan Penetrasi Media Sosial}

\section{(Januari 2017)}

Pengguna Media Sosial Mobile Aktif

Pengguna Media Sosial Aktif

Pengguna Ponsel Terdaftar
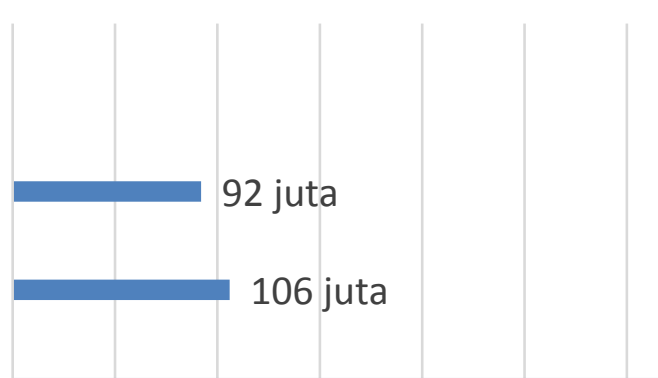

\section{Populasi}
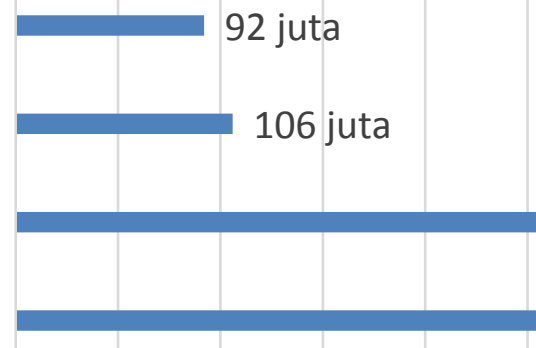

262 juta

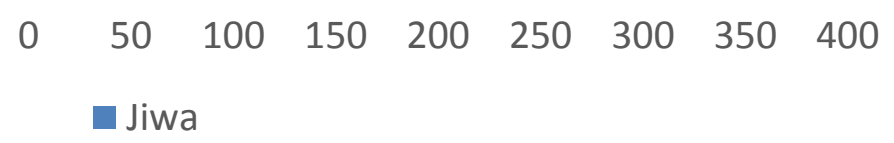

Sumber: databoks.co.id

Banyaknya pengguna smartphone dan pengguna media sosial di Indonesia, menjadikan media sosial menjadi suatu alat yang mudah digunakan bagi para pelaku usaha untuk melakukan kegiatan pemasaran. Dikutip dari CNN Indonesia, Ayuwuragil (2017) menyatakan bahwa menurut Kementrian Koperasi dan Usaha Kecil Menengah (Kemenkop UMKM), sebanyak 3,79 juta UMKM telah memanfaatkan platform online dalam memasarkan produknya. Salah satunya yaitu jenis UMKM di industri pangan/kuliner.

UMKM pangan/kuliner merupakan UMKM yang paling besar pertumbuhannya di Indonesia. Airlangga Hartarto, Menteri Perindustrian menyatakan bahwa pertumbuhan indusri makanan dan minuman semakin meningkat. Pada tahun 2016 pertumbuhannya sebesar 8,46\% dan meningkat menjadi 9,23\% pada tahun 2017 (Yasmin, 2018), tak terkecuali di daerah Jatinangor, Sumedang. Daerah yang sedang berkembang menjadi salah satu daerah pusat pendidikan dengan berdirinya beberapa kampus besar seperti Universitas Padjajaran, ITB, IKOPIN, dan IPDN ini menunjang semakin berkembangnya UMKM Makanan dan Minuman di sekitar daerah tersebut, seiring dengan peningkatan jumlah konsumen di daerah tersebut.

Peningkatan jumlah konsumen yang menunjang peningkatan permintaan, salah satunya terhadap produk kuliner yang menjadi kebutuhan primer membuka peluang besar bagi para pelaku usaha mikro kecil menengah (UMKM) Makanan dan Minuman untuk terus tumbuh dan berkembang. Sejalan dengan hal tersebut muncul banyak UMKM makanan dan minuman di daerah Jatinangor yang menyebabkan meningkatnya persaingan. Dengan perkembangan media pemasaran digital serta pergeseran perilaku konsumen terutama generasi milenial yang banyak menggunakan teknologi dalam kehidupan sehari-hari sehingga selalu menuntut sesuatu yang instan, mudah, dan cepat (Lyons, 2004) menyebabkan para pelaku UMKM Makanan dan Minuman di daerah Jatinangor perlu mengadopsi pemanfaatan media sosial dalam memaksimalkan 
pemasaran produk yang mereka miliki. Adapun salah satu media sosial yang banyak digunakan sebagai media pemasaran karena dianggap paling efektif, efisien serta tepat sasaran diantaranya instagram dan facebook.

Berdasarkan hasil survey yang dilakukan pada pemilik UMKM Makanan dan Minuman di daerah Jatinangor, diketahui bahwa sebagian besar UMKM tersebut belum memaksimalkan penggunaan media sosial sebagai sarana untuk mempromosikan atau memasarkan produk usahanya. Salah satu kendala yang dihadapi oleh UMKM tersebut adalah terbatasnya pasar untuk mengembangkan pemasaran produk karena ketidakmampuan para pelaku usaha untuk melakukan praktik pemasaran yang efektif dan berbiaya rendah. Padahal, saat ini terdapat cukup banyak aplikasi yang menawarkan fiturfitur yang dapat digunakan secara gratis untuk mempromosikan maupun menawarkan produk-produk yang dimiliki, diantaranya facebook yang menyediakan fitur facebook pages dan Instagram yang menyediakan fitur Instagram for Business.

Berdasarkan kondisi tersebut, penelitian ini membahas lebih lanjut mengenai pemanfaatan media digital khususnya media sosial bagi UMKM dalam menjalankan kegiatan usahanya. Penelitian ini dilakukan karena masih minimnya pemanfaatan media sosial oleh para pelaku usaha di wilayah Jatinangor untuk kegiatan promosi dan pemasaran dari usaha mereka.

Tujuan dan manfaat dari penulisan ini antara lain adalah untuk mendapatkan gambaran mengenai bagaimana kesiapan UMKM-UMKM di Jatinangor, khususnya UMKM makanan dan minuman dalam mengadopsi teknologi khususnya penggunaan media sosial Instagram dalam kegiatan usahanya dan juga pemanfaatan media sosial sebagai sarana untuk melakukan pemasaran digital (digital marketing).

\section{LANDASAN TEORI}

1. UMKM

UMKM merupakan bentuk bisnis yang paling dominan di Indonesia. Badan Pusat Statistik (BPS) memberikan definisi UMKM yang dibagi berdasarkan kuantitas tenaga kerja. Usaha kecil merupakan usaha yang memiliki jumlah tenaga kerja 5 orang sampai dengan 19 orang, sedangkan usaha menengah merupakan usaha yang memiliki jumlah tenaga kerja 20 orang sampai dengan 99 orang.

Pada UU no 20 Tahun 2008 tentang Usaha Mikro, Kecil dan Menengah (UMKM), pengertian UMKM dibagi kedalam 3 kriteria, antara lain Usaha Mikro, Usaha Kecil dan Usaha Menengah dengan penjelasan seperti terlihat pada Tabel 1.

Tabel 1. Kriteria UMKM berdasarkan UU no 20 Tahun 2008 tentang UMKM

\begin{tabular}{|c|l|c|c|}
\hline \multirow{2}{*}{ NO } & \multirow{2}{*}{ URAIAN } & \multicolumn{2}{|c|}{ KRITERIA } \\
\cline { 3 - 4 } & & ASSET & OMZET \\
\hline 1 & Usaha Mikro & Max 50 jt & Max 300 jt \\
\hline 2 & Usaha Kecil & $>50 \mathrm{jt}-500 \mathrm{jt}$ & $>300 \mathrm{jt}-2,5 \mathrm{M}$ \\
\hline 3 & Usaha Menengah & $>500 \mathrm{jt}-10 \mathrm{M}$ & $>2,5 \mathrm{M}-50 \mathrm{M}$ \\
\hline
\end{tabular}

Sumber: bumn.go.id

Sektor Usaha Mikro Kecil dan Menengah memiliki karakteristik tersendiri yang dapat membedakannya dengan usaha berskala besar. Dalam perspektif 
perkembangannya, menurut Krisnawati (2018) UMKM dapat diklasifikasikan menjadi 4 (empat) kelompok yaitu:

1. Livelihood Activities, merupakan UMKM yang lebih umum dikenal sebagai sektor informal.

2. Micro Enterprise, merupakan UMKM yang memiliki sifat pengrajin tetapi belum memiliki sifat kewirausahaan.

3. Small Dynamic Enterprise, merupakan UMKM yang telah memiliki jiwa kewirausahaan dan mampu menerima pekerjaan subkontrak dan ekspor.

4. Fast Moving Enterprise, merupakan UMKM yang telah memiliki jiwa kewirausahaan dan akan melakukan transformasi menjadi Usaha Besar (UB).

Dalam era digital saat ini, UMKM di Indonesia semakin berkembang dengan cepat. UMKM memanfaatkan teknologi khususnya media sosial sebagai sarana untuk melakukan pemasaran digital (digital marketing) untuk menjalankan kegiatan usahanya. Namun, Susilo (2010) menyatakan bahwa UMKM masih menghadapi beberapa kendala dalam meningkatkan daya saing dan kinerja UMKM. Faktor-faktor kendala tersebut yaitu adanya keterbatasan pada permodalan, keterbatasan akses pada pasar, dan juga adanya keterbatasan pada akses informasi mengenai sumberdaya dan teknologi.

\section{Pemasaran Digital}

Pemasaran digital adalah bentuk pemasaran langsung yang menghubungkan konsumen dengan penjual secara elektronik menggunakan teknologi interaktif seperti email, situs web, media sosial dan newsgroup, televisi interaktif, komunikasi seluler, dan sebagainya (Kotler dan Armstrong, 2009). Pemasaran digital memfasilitasi many-tomany communications karena tingkat konektivitas yang tinggi dan biasanya dimanfaatkan untuk mempromosikan produk atau layanan pada waktu yang tepat, relevan, bersifat lebih personal dan hemat biaya (Satyo, 2009). Aktivitas-aktivitas pemasaran dilakukan secara intensif menggunakan media digital, mulai dari promosi atau penawaran produk hingga penjualan produk.

Selain memudahkan pebisnis memantau dan menyediakan segala kebutuhan dan keinginan calon konsumen, pemasaran digital juga memudahkan calon konsumen untuk dapat mencari dan memperoleh informasi produk hanya dengan menjelajah dunia maya. Pembeli kini semakin mandiri dalam membuat keputusan pembelian berdasarkan hasil pencarian yang dilakukanya kapanpun dan dimanapun. Pemasaran digital dapat menjangkau seluruh masyarakat di manapun mereka berada tanpa ada batasan geografis ataupun waktu.

Pemanfaatan pemasaran digital tidak hanya dilakukan oleh pemilik usaha-usaha besar, namun juga dapat dimanfaatkan oleh setiap elemen pelaku usaha, salah satunya bagi para pemilik UMKM. Perkembangan teknologi digital memungkinkan para pelaku UMKM untuk memasarkan produknya secara online. Pemanfaatan media online dapat menjadi pilihan tepat bagi para UMKM untuk mengembangkan bisnis yang dijalankannya. Mudahnya akses internet saat ini, besarnya manfaat yang didapatkan, serta murahnya biaya yang dibutuhkan menjadi alasan utama UMKM perlu memanfaatkan media online sebagai solusi tepat untuk memperluas jangkauan bisnisnya.

Terdapat dua point utama manfaat pemasaran digital yang dijelaskan oleh Hermawan (2012:21) yakni: 
a. Biayanya yang relatif murah

Pemasaran digital jauh memakan biaya yang lebih murah dan juga menjangkau calon konsumen dengan sangat luas dibandingkan dengan periklanan konvensional.

b. Muatan informasi yang besar

Pemasaran digital menyediakan sejumlah informasi yang besar dibandingkan dengan media konvensional seperti media cetak, radio dan televisi. Pelaku usaha dapat menyimpan data secara akurat yang diperlukan oleh perusahaan dan mampu membantu perluasan bisnis.

Pemasaran dengan memanfaatkan media digital digunakan sebagai platform pembangun brand image suatu perusahaan atau produk dan juga mendukung fungsi penjualan terhadap target konsumen. Morissan (2010: 324) membagi tujuan pemasaran digital sebagai berikut:

a. Penyebaran Informasi

Salah satu bentuk tujuan dari pemasaran digital adalah penyedian informasi yang secara lengkap serta mendalam mengenai suatu produk perusahaan. Perusahaan yang menggunakan pemasaran digital memiliki peluang lebih besar dalam mendapatkan pembeli. Dan secara singkat penggunaan pemasaran digital yang dilakukan oleh perusahaan merupakan media paling tepat dalam menyebarkan informasi kepada khalayak banyak.

b. Mencipatakan Kesadaran

Bagi perusahaan yang kecil yang memiliki budget terbatas dalam melakukan promosi, pemasaran digital merupakan media alternatif yang mampu menciptakan kesadaran yang lebih efektif dibandingkan media konvensional, sehingga penggunaan pemasaran digital sangat bermanfaat sebagai media yang menciptakan kesadaran organisasi dan perusahaan serta jasa atau produk yang dihasilkan oleh perusahaan atau organisasi.

c. Tujuan Riset

Pemasaran digital tidak hanya digunakan sebagai alat pemasaran sebuah perusahaan, namun juga digunakan sebagai alat untuk meriset pasar serta mengumpulkan informasi dari para pesaing dan juga target konsumen.

d. Membangun Persepsi

Perusahaan menggunakan pemasaran digital sebagai media yang dirancang guna membangun persepsi mengenai image perusahaan terhadapa khalayak banyak.

e. Percobaan Produk

Perusahaan menggunakan pemasaran digital untuk melakukan percobaan produk mereka, perusahan juga mengeluarkan sejenis campaign yang menawarkan kupon elektornik kepada target konsumen atau konsumen supaya mendorong agar bersedia mencoba produk mereka.

f. Meningkatkan Pelayanan

Banyak perusahaan yang merasakan manfaat dari penggunaan pemasaran digital. Selain memberikan informasi secara lengkap, pemasaran digital juga menjawab pertanyaan serta keluhan dari pelanggan. Peran ini juga pada akhirnya dapat memperbaiki pelayanan yang diberikan kepada pelanggan dan konsumenya.

g. Meningkatkan Distribusi

Pemasaran digital merupakan media yang mempunyai banyak tools dalam melakukan pemasaran yang dilakukan oleh perusahaan, yang mana dengan tools yang ada perusahaan dapat bekerja sama untuk mempromosikan dan menampilkan 
produk mereka, diantara tools tersebut adalah website, platform media social, dan sebagainya.

\section{Media Sosial}

Menurut Thoyibie (2010), media sosial adalah konten berisi informasi yang dibuat oleh orang yang memanfaatkan teknologi penerbitan, mudah diakses dan dimaksudkan untuk memfasilitasi komunikasi, mempengaruhi, serta berinteraksi dengan sesama dan dengan khalayak umum. Dewasa ini, praktek pemasaran melalui media sosial mulai berkembang dan digunakan sebagai alat pemasaran produk dan mempromosikan brand suatu perusahaan. Media sosial menjadi tempat berkumpulnya orang-orang yang ingin berbagi informasi dan tempat untuk mencari teman baru serta berinteraksi dengan teman lainnya secara online. Media sosial yang berkembang sangat pesat di negara Indonesia ialah Instagram, facebook, twitter, dan sejenisnya.

Semakin banyaknya masyarakat yang menggunakan media sosial, terutama Instagram menginspirasi para pemasar (marketer) untuk memanfaatkannya sebagai media komunikasi pemasaran dari produk maupun jasa yang dihasilkan. Dimana semua orang tidak hanya menjadi user, namun juga dapat menjadi publisher. Dapat dikatakan bahwa media sosial merupakan platform yang sangat efektif untuk berkomunikasi dan mendengarkan pendapat konsumen, seperti memberi kritik, saran serta komplain. Meskipun kegiatan komunikasi pemasaran dilakukan secara online, namun efek dari pemasaran yang dilakukan pun bisa berdampak offline yaitu melalui mulut ke mulut (word of mouth). Jika mampu mengkombinasikan model pemasaran online dan offline, maka dapat dipastikan produk/ jasa yang ditawarkan akan lebih mudah untuk diterima oleh konsumen (Agatha, 2015:5).

Praktek pemasaran melalui sosial media banyak diadopsi oleh pelaku usaha di berbagai sektor guna mengembangkan bisnis yang dimiliki, namun demikian masih cukup banyak pelaku usaha yang belum memanfaatkan secara maksimal fungsi dari media sosial sebagai media pemasaran digital. Salah satunya oleh para pelaku usaha mikro kecil dan menengah (UMKM), khususnya di daerah terpencil yang cenderung belum mengetahui perkembangan media digital untuk proses pemasaran. UMKM harus cermat dalam memilih media sosial yang sesuai dengan tujuan pemasarannya (Safitri, 2015; Kautsarina, 2013). Seperti facebook yang lebih cocok untuk tujuan menjangkau lebih banyak audiens karena karakter penggunanya meluas dari semua level sehingga UKM dapat membangun relasi (relationship) dan kesadaran (awareness) dengan pemanfaatan fitur events, update satus, maupun membalas langsung feedback dari konsumen. UMKM dapat memaksimalkan penggunaan Facebook sebagai media pemasaran digital dengan menggunakan fitur pages dan dengan membuat updates yang deskriptif disertai foto dan link website untuk call-to-action. Sementara itu, untuk Instagram cocok untuk membangun awareness dan menciptakan hubungan dengan konsumen, terlebih dengan hadirnya fitur Instagram bisnis yang menawarkan berbagai layanan yang memudahkan konsumen untuk berinteraksi dengan konsumen.

Berdasarkan hasil survei apjii, dari sekian banyak media sosial di Indonesia yang berkembang di masyarakat, Instagram merupakan salah satu yang paling diminati di masyarakat. Sesuai dengan data yang diperoleh, pengguna Instagram adalah $15 \%$ atau 19,9 juta, mendapatkan urutan kedua setelah Facebook (http://isparmo.web.id). Pertumbuhan pengguna Instagram meningkat $8 \%$ dari $7 \%$ atau 17.850 .000 pengguna di tahun 2015 (http://lunariastudio.com). 


\section{METODOLOGI PENELITIAN}

Dalam penelitian ini, penulis akan menggunakan metode penelitian desktiptif kualitatif dengan pendekatan studi kasus dan teknik pengambilan data yaitu observasi dan wawancara.

Menurut Moleong (2006:6), penelitian kualitatif adalah penelitian yang bermaksud untuk memahami fenomena tentang apa yang dialami oleh subjek peneliti seperti perilaku, persepsi, motivasi, atau tindakan. Menurut Nawawi dan Martini (1994 : 73), metode deskriptif adalah metode yang melukiskan keadaan suatu objek atau peristiwa tertentu berdasarkan fakta-fakta yang tampak yang kemudian diiringi dengan upaya pengambilan kesimpulan umum berdasarkan fakta-fakta histori tersebut. Menurut Suharsimi Arikunto (2002:120) penelitian studi kasus adalah suatu penelitian yang dilakukan secara intensif, terinci, dan mendalam terhadap suatu organisasi, lembaga, dan gejala tertentu. Data studi kasus dapat diperoleh dari semua pihak yang bersangkutan, dengan kata lain dalam studi ini dikumpulkan dari sumber yang bersangkutan (Nawawi, 2003: 1) atau merupakan pemilik Usaha Mikro Kecil dan Menengah (UMKM) Makanan dan Minuman di daerah Jatinangor. Pada dasarnya penelitian dengan jenis studi kasus bertujuan untuk mengetahui tentang sesuatu hal secara mendalam.

Penulis menggunakan metode penelitian kualitatif deskriptif dengan pendekatan studi kasus untuk mengetahui kesiapan para pelaku usaha mikro kecil dan menengah (UMKM), khususnya UMKM Makanan dan minuman di Jatinangor dalam mengadopsi media sosial Instagram Bisnis untuk memaksimalkan pemasaran dan promosi produk yang dimiliki.

\section{HASIL PENELITIAN}

Jatinangor merupakan wilayah yang memiliki banyak UMKM yang terdiri dari berbagai unit usaha dan salah satu yang paling berkembang di Jatinangor adalah UMKM di bidang kuliner. Adanya beberapa perguruan tinggi di Jatinangor seperti IPDN, ITB, Unpad dan IKOPIN membuat UMKM makanan dan minuman di wilayah ini terus menerus bertambah. Namun, berdasarkan hasil observasi di lapangan, masih banyaknya UMKM makanan dan minuman di Jatinangor berjualan dengan cara yang konvensional dan belum memanfaatkan teknologi khususnya media sosial dalam kegiatan usaha mereka. Dalam penelitian ini media sosial yang difokuskan yaitu aplikasi Instagram dengan menggunakan fitur Instagram for Business.

Peneliti mengambil sebanyak 30 UMKM makanan dan minuman di Jatinangor yang belum memanfaatkan atau belum menggunakan media sosial khususnya Instagram for business dalam menjalankan kegiatan bisnisnya dan dalam kegiatan pemasarannya (digital marketing). Adapun rincian UMKM makanan dan minuman di Jatinangor yang menjadi sample pada penelitian ini adalah sebanyak 24 UMKM makanan dan 6 UMKM minuman dengan rincian seperti yang terlihat pada Tabel 2 .

Tabel 2 Data Responden Penelitian

\begin{tabular}{|l|c|c|c|c|c|}
\hline No & Nama UMKM & Jenis UMKM & No & Nama UMKM & Jenis UMKM \\
\hline 1 & Anak Gadih Company & Makanan & 16 & Md Tomyam & Makanan \\
\hline
\end{tabular}




\begin{tabular}{|l|l|l|l|l|c|}
\hline 2 & Baso Tahu Hoki 777 & Makanan & 17 & Ngemilk & Minuman \\
\hline 3 & B'Co & Makanan & 18 & Putput Thai Tea & Minuman \\
\hline 4 & Bola-Bola Ubi & Makanan & 19 & Rumah Makan Uni & Makanan \\
\hline 5 & Cahaya Cake & Makanan & 20 & Singkong Keju & Makanan \\
\hline 6 & Camilanoz & Makanan & 21 & Soto Ayam & Makanan \\
\hline 7 & Chocolate Changer & Minuman & 22 & Spageti Wawa & Makanan \\
\hline 8 & Copas Ice Blend & Minuman & 23 & Sushi Rice Bowl & Makanan \\
\hline 9 & Fresh Milk & Minuman & 24 & Tahu Sumedang Hj. Ateng & Makanan \\
\hline 10 & Jafa Cake and Cookies & Makanan & 25 & Tango Express & Makanan \\
\hline 11 & Kantin Ibu Eyang & Makanan & 26 & Waroeng Favorit & Makanan \\
\hline 12 & Kedai The Edun & Makanan & 27 & Warung Surabi Jatinangor & Makanan \\
\hline 13 & Makroni Mahot & Makanan & 28 & Wilen's Cupcake & Makanan \\
\hline 14 & Martabak Tegal Bandung & Makanan & 29 & Willy Juice & Minuman \\
\hline 15 & Martabak Telor Mini & Makanan & 30 & Keripik Pisang & Makanan \\
\hline
\end{tabular}

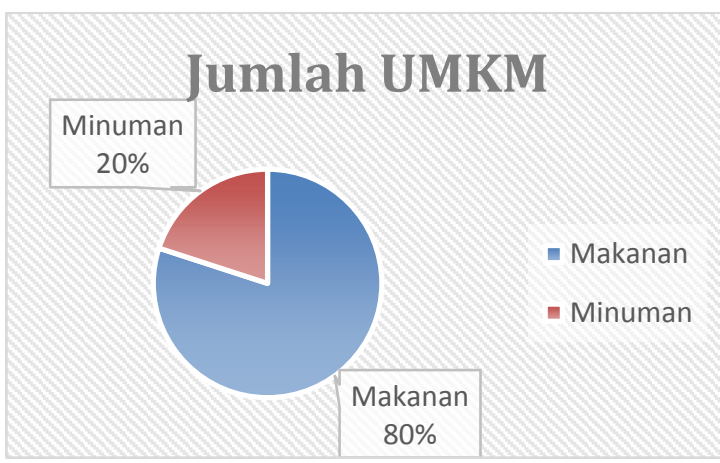

Presentase Responden Penelitian

Berdasarkan hasil pengumpulan data yang dilakukan dengan wawancara kepada masing-masing UMKM, para pelaku usaha belum mengetahui adanya fitur Instagram for business pada aplikasi Instagram. Mereka masih menggunakan Instagram personal dalam melaksanakan kegiatan bisnisnya. Sementara itu, fitur Instagram for Business dapat memberikan sejumlah informasi-informasi yang menunjang kegiatan bisnis dan pemasaran bagi para UMKM. Instagram for Business dapat memberikan informasi berupa data statistik jumlah pengunjung akun Instagram, data lokasi demografi dari pengikut akun Instagram, konten mana saja yang paling disukai oleh pengikut akun Instagram, serta berapa banyak pengikut baru dalam waktu sepekan.

Setelah responden diberikan informasi mengenai penggunaan dan manfaat dari fitur Instagram for Business, sejumlah UMKM menyatakan bahwa mereka tertarik untuk memanfaatkan media sosial khususnya fitur Instagram for Business dalam mendukung kegiatan bisnisnya dan dalam kegiatan pemasarannya (digital marketing). Bahkan ada beberapa UMKM yang langsung menggunakan fitur Instagram for Business setelah peneliti memberikan gambaran mengenai fitur tersebut. 
Namun, berdasarkan hasil wawancara, terdapat beberapa UMKM yang memiliki kendala-kendala dalam menggunakan media sosial secara optimum, khususnya aplikasi Instagram. Kendala-kendala tersebut berupa keterbatasan pemahaman mengenai penggunaan aplikasi media sosial, usia para pelaku usaha yang dominan diatas 40 tahun sehingga para pelaku usaha mengalami kesulitan dalam menggunakan fitur-fitur media sosial terutama pada Instagram. Selain itu, kendala berikutnya adalah kurangnya resource dalam mengelola media sosial terutama Instagram. Mereka lebih berfokus pada proses produksi dan proses penjualan produknya.

Ketika responden ditanyakan mengenai kesiapan mereka dalam pemanfaatan fitur Instagram for Business dalam kegiatan bisnis mereka, mereka menyatakan bahwa mereka tertarik dan mau menerapkan fitur tersebut akan tetapi mereka menyadari bahwa kesiapan mereka masih belum maksimal Karena kendala-kendala yang sudah dipaparkan sebelumnya. Mereka menyatakan bahwa mereka memerlukan cukup waktu untuk mengadopsi teknologi dalam menunjang kegiatan usaha, khususnya pemanfaatan media sosial, karena rata-rata usia responden diatas 40 tahun maka penggunaan aplikasi media sosial sulit untuk di aplikasikan oleh mereka. Hal ini didukung dengan adanya data berdasarkan hasil survey yang dilakukan oleh Asosiasi Pengguna Jasa Internet Indonesia (APJII) bahwa pengguna internet kelompok usia 35-54 tahun hanya sebesar 29,55\% dari total populasi. Penggunaan internet masih di dominasi oleh kelompok usia 19-34 tahun sebanyak 49,52\%.

\section{KESIMPULAN}

Perkembangan media digital menunjang segala aktivitas bisnis terutama dalam hal pemasaran dan promosi produk yang dimiliki. Salah satu media digital yang dianggap paling efektif dalam menunjang pemasaran digital di era globalisasi saat ini yaitu media sosial. Menyikapi hal tersebut, berbagai platform media sosial terus melakukan perbaruan guna menunjang kebutuhan para pelaku usaha dalam memanfaatkan media sosial sebagai media pemasaran digital. Seperti yang dilakukan oleh Instagram yang mengembangkan fitur Instagram for Business.

Fitur Instagram for Business diklaim mampu memaksimalkan pemasaran maupun promosi produk yang dimiliki oleh pelaku usaha. Fitur yang menyediakan berbagai layanan yang memudahkan konsumen dan pemilik usaha dalam berinteraksi, serta memudahkan pemilik usaha dalam menganalisis pasar ini mampu menjadi salah satu media pemasaran berbasis online yang dapat digunakan secara gratis.

Berbagai kelebihan yang ditawarkan oleh fitur Instagram for Business membuat 30 pemilik UMKM Makanan dan Minuman di daerah Jatinangor yang menjadi responden dalam penelitian ini merasa perlu untuk memanfaatkan fitur tersebut sebagai salah satu media promosi bagi usaha yang mereka miliki. Meskipun dihadapkan pada berbagai kendala seperti minimnya resource, keterbatasan pemahaman dalam memaksimalkan penggunaan fitur, dan berbagai kendala lainnya. Namun, para responden tersebut dengan antusias dan dibantu oleh peneliti langsung mengaktifkan fitur Instagram for Business milik usaha mereka sendiri. Para responden tersebut ingin mengadopsi penggunaan media sosial yang dianggap mampu memaksimalkan pemasaran produk yang mereka miliki.

\section{DAFTAR PUSTAKA}


APJII. (2018, March 22). Asosiasi Penyelenggara Jasa Internet Indonesia. Diambil kembali dari https://apjii.or.id/content/read/104/348/BULETIN-APJII-EDISI-22--Maret-2018

Arikunto, S. (2002). Metodologi Penelitian. Jakarta: PT Rineka Cipta.

Ayuwuragil, K. (2017, November 15). CNN Indonesia. Diambil kembali dari https://www.cnnindonesia.com/ekonomi/20171115161037-78-

255819/kemenkop-ukm-379-juta-umkm-sudah-go-online

BPS. (t.thn.). Industri Mikro dan Kecil. Jakarta: bps.go.id.

BUMN. (2015, February 3). bumn.go.id. Diambil kembali dari http://bumn.go.id/jamkrindo/berita/0-KRITERIA-USAHA-MIKRO-KECILDAN-MENENGAH-MENURUT-UU-NO-20-TAHUN-2008-TENTANGUMKM

Chandra, A. A. (2017, February 6). detikFInance. Diambil kembali dari https://finance.detik.com/berita-ekonomi-bisnis/d-3414745/pendapatan-perkapita-ri-naik-jadi-rp-4796-jutatahun

Fatwan, S. (2009). Intellectual Capital. Jakarta: PT Gramedia Pustaka Utama.

Hermawan, A. (2012). Komunikasi Pemasaran. Jakarta: Erlangga.

katadata. (2017, August 29). databoks. Diambil kembali dari https://databoks.katadata.co.id/datapublish/2017/08/29/pengguna-ponselindonesia-mencapai-142-dari-populasi

katadata. (2018, February 23). databoks. Diambil kembali dari https://databoks.katadata.co.id/datapublish/2018/02/23/usia-produktifmendominasi-pengguna-internet

Kazali, R. (2011). Cracking Zone. Jakarta: PT Gramedia Pustaka Utama.

Kotler, P., \& Amstrong, G. (Principal of Marketing). 2011. Prentice Hall: Pearson.

Krisnawati, D. (2018). Peran Perkembangan Teknologi Digital Pada Strategi Pemasaran Dan Jalur Distribusi UMKM di Indonesia. Jurnal Manajemen Bisnis Krisnadwipayana Vol.6 No.1.

Moleong, L. J. (2006). Metodologi Penelitian Kualitatif. Bandung: PT Remaja Rosdakarya.

Morissan. (2010). Periklanan. Jakarta: Kencana.

Mutmainah, D. A. (2016, November 21). CNN Indonesia. Diambil kembali dari https://www.cnnindonesia.com/ekonomi/20161121122525-92-

174080/kontribusi-umkm-terhadap-pdb-tembus-lebih-dari-60-persen

Nawawi, H. (2003). Metode Penelitian Bidang Sosial. Yogyakarta: Gajahmada University.

Nawawi, H., \& Martini, M. (1994). Penelitian Terapan. Yogyakarta: Gajahmada University.

Sanjaya, R., \& Tarigan, J. (2009). Creative Digital Marketing. Jakarta: PT Elex Media Komputindo.

Tjiptono, Fandy, Chandra, G., \& Adriana, D. (2008). Pemasaran Strategik. Yogyakarta: ANDI.

Yasmin, P. A. (2018, April 23). detikFinance. Diambil kembali dari https://finance.detik.com/industri/d-3985814/menperin-industri-makanan-danminuman-tumbuh-923 